\title{
Yield Components of Day-neutral and Short-day Strawberry Varieties on Raised Beds in British Columbia
}

\author{
T.E. Baumann', G.W. Eaton ${ }^{2}$, and D. Spaner ${ }^{3}$ \\ Department of Plant Science, The University of British Columbia, 2357 Main \\ Mall, Vancouver, B.C. V6T 1Z4, Canada \\ Additional index words. two-dimensional partitioning, hill-row, raised beds, Fragaria \\ $\times$ annassa, plastic mulch
}

\begin{abstract}
Eight day-neutral and seven short-day strawberry (Fragaria ×ananassa,Duch.) varieties were evaluated on raised beds during 1990 and 1991 in the Fraser River valley, B.C. Among day-neutral varieties in 1990, total variation in marketable yield originated in fruit count $(\mathbf{2 6 \%})$, total yield $(\mathbf{1 8 \%})$, average leaf size $(22 \%)$, and runner count $(\mathbf{1 9 \%})$ per plant. In 1991, total variation in marketable yield originated in fruit count $(38 \%)$, runner count $(\mathbf{2 3 \%})$, crown count $(\mathbf{1 3 \%})$, and total yield $(\mathbf{1 6 \%})$ per plant. 'Selva' was one of the most productive day-neutral varieties and had the heaviest fruit and the fewest culls during both years of the study. The short-day varieties had uniformly low yields of marketable fruit during the establishment year, 1990. Variation in marketable yield in 1991 originated in runner count $(34 \%)$, total yield $(18 \%)$, and fruit count $(16 \%)$ per plant. Of the short-day varieties in 1991, 'Shuswap' had the highest marketable yield and, along with 'Pajaro' and 'Sequoia', had the fewest culls. 'Shuswap' was a prolific producer of runners, while 'Sumas' and 'Redcrest' yielded well without prolific runner production.
\end{abstract}

Commercial strawberry production in British Columbia is found mainly in the lower Fraser River valley near Vancouver. In 1990, $5600 \mathrm{t}$ of marketable fruit was harvested in this area for a retail value of $\$ 9.2$ million (Province of British Columbia, 1992). About $90 \%$ of this production is for the processing industry and normally involves short-day varieties grown on flat beds in matted rows. 'Totem' accounts for almost $80 \%$ of all strawberries produced in the province (Lawrence, 1989). A rapidly increasing domestic market for fresh fruit has stimulated interest in nontraditional cultural practices and new strawberry varieties. Recent work has examined the potential for introducing day-neutral varieties into British Columbia. Such work has involved a system of planting on raised beds, with plastic mulch and trickle irrigation on the raised beds. Short-day varieties also have been tested in the same system (Baumann and Eaton, 1991; Baumann

\footnotetext{
Received for publication 14 Dec. 1992. Accepted for publication 22 Apr. 1993. These studies were supported by the Fraser Valley Strawberry Growers Association, the British Columbia Strawberry Processors, the Productivity Enhancement Program of the Canada-British Columbia Agri-Food Regional Development Subsidiary Agreement, and the Natural Sciences and Engineering Research Council of Canada Collaborative Research and Development Program. Use of trade names does not imply either endorsement or criticism of products named or not named. The cost of publishing this paper was defrayed in part by the payment of page charges. Under postal regulations, this paper therefore must be hereby marked advertisement solely to indicate this fact.

'Research Associate.

${ }^{2}$ Professor.

${ }^{3}$ Research Assistant.
}

et al., 1991, 1993; Hesketh et al., 1990).

Strawberry marketable yield is made up of several intercorrelated components (Hesketh et al., 1990; Swartz et al., 1985). Varieties selected based on their performance under one cultural system may perform differently under other systems. Yield component contributions may depend on the variety and the production system.

This study was designed to explore the contribution and importance of several components of strawberry marketable yield. Eight day-neutral and seven short-day strawberry varieties were grown on raised beds. A second objective was to identify strawberry varieties well adapted to this system under British Columbian growing conditions.

D ay-neutral variety evaluation. Eight day-neutral strawberry varieties were planted in 1990 in five randomized complete blocks with 20 plants per plot. The varieties used were 'Fern', 'Fort Laramie', 'Hecker', 'Irvine', 'Ozark Beauty', 'Selva', 'Tribute', and 'Tristar'. Krause Brothers Farms provided an experimental site on sandy loam soil at a commercial farm in Langley, B.C. Cold-stored runners were planted on raised beds formed $107 \mathrm{~cm}$ apart, $30 \mathrm{~cm}$ high, and $50 \mathrm{~cm}$ wide at the top (Baumann and Peters, 1991). There were two rows of plants in a staggered arrangement on each bed. The distance between the rows on a bed was $20 \mathrm{~cm}$. Plants were spaced $30 \mathrm{~cm}$ apart in the rows, an arrangement that resulted in a final density of 61,486 plants/ha. Trickle irrigation tubes were placed between the two rows, and the beds were covered with black plastic mulch. Data were collected in the planting year and again in 1991.

All blossoms that emerged during the first
3 weeks after planting were removed. The runners were counted three times per season and subsequently removed. Flowers were counted on five randomly chosen trusses for each of 10 plants/plot. Ten plants per plot were used for runner, crown, and truss counts and leaf size measurements. The sum of the lengthwidth products of the three leaflets provided an index of leaf size. Fruit were harvested weekly throughout the summer and early fall. Marketable fruit and culls were weighed, and an index of fruit size (average weight of 25 marketable berries, weighted by yield at each harvest) was measured for each plot. Culls were those fruit deemed not marketable as fresh fruit.

The variables computed per plant were leaf size; runner, crown, truss, and flower counts; and total and marketable fruit yields. A plant's total yield divided by the fruit-size index was an estimate of the plant's berry count.

Data were tested by analysis of variance. Regression residuals were computed to remove the effects of replication, then correlations were calculated between marketable yield and its components (SAS Institute, 1985). The variation in marketable yield was partitioned into its components by the two-dimensional partitioning (TDP) method of Eaton et al. (1986). Themarketable yieldcomponents were modeled additively in the following sequential order: runner count; leaf size; crown, truss, flower, and berry count; and total yield. All components and marketable yield were analyzed per plant.

Short-day variety evaluation. Seven short-day strawberry varieties-Pajaro, Puget Beauty, Redcrest, Shuswap, Sumas, Totem, and Sequoia-were evaluated by the same protocol as were the day-neutral varieties, with the following exceptions: 'Pajaro' and 'Sequoia' were planted in two blocks each, while the others were in four blocks each. Plants were set $20 \mathrm{~cm}$ apart in the rows, an arrangement that resulted in a planting density of 92,225 plants/ha. Varieties were compared using orthogonal single degree-of-freedom contrasts (Steel and Torrie, 1980). Type III sums of squares were used in the analysis of variance because of the unequal numbers of blocks for the various varieties in the design (SAS Institute, 1985).

Day-neutral varieties. A preliminary analysis was computed using the combined data from 2 years of trials. Year effects accounted for $65 \%$ of the total variation in marketable yield and the variety $\mathbf{x}$ year interaction accounted for $12 \%$ (data not shown). As the yields were much higher in the second year and some varietal rank reversals occurred, the years then were analyzed separately.

In the first year (1990) variety differences accounted for $56 \%$ of the variation in marketable yield (Table 1). Variation in marketable yield arose from fruit count $(26 \%)$, total yield (18\%), average leaf size (22\%), and runner count (19\%) (Table 1). Crowns, trusses, and flowers accounted for little variation in marketable yield in 1990. Ten percent of the variation was unexplained residual. Marketable yield correlated strongly with total yield 
Table 1. Two-dimensional partitioning of the sum of squares for marketable yield for day-neutral strawberry varieties.

\begin{tabular}{|c|c|c|c|c|c|c|c|c|c|c|c|}
\hline \multirow[b]{4}{*}{ Source } & \multirow[b]{4}{*}{$\mathrm{df}$} & \multicolumn{10}{|c|}{ Variable } \\
\hline & & \multicolumn{9}{|c|}{ Independent } & \multirow{3}{*}{$\begin{array}{c}\text { Dependent } \\
\text { Marketable } \\
\text { yield }^{x}\end{array}$} \\
\hline & & \multirow{2}{*}{$\begin{array}{c}\text { Runner } \\
\text { count }\end{array}$} & \multirow{2}{*}{$\begin{array}{c}\text { Leaf } \\
\text { size }\end{array}$} & \multicolumn{4}{|c|}{ Count } & \multirow{2}{*}{$\begin{array}{l}\text { Total } \\
\text { yield }\end{array}$} & \multirow[b]{2}{*}{$\operatorname{Res}^{z}$} & \multirow[b]{2}{*}{$X X^{y}$} & \\
\hline & & & & - Crowns & Trusses & Flowers & Fruit & & & & \\
\hline \multicolumn{12}{|c|}{1990} \\
\hline Total & 39 & $19^{* *}$ & $22^{* *}$ & 2 & 2 & 1 & $26^{* *}$ & $18^{* *}$ & $10^{* *}$ & $0^{\mathrm{w}}$ & 100 \\
\hline Block & 4 & 1 & 0 & $0^{*}$ & 0 & 0 & 4 & $7^{* *}$ & 0 & 4 & $16^{* *}$ \\
\hline Variety & 7 & $14^{* *}$ & $16^{* *}$ & $1^{* *}$ & $1^{* *}$ & 0 & $9^{*}$ & $6^{* *}$ & $5^{* *}$ & 4 & $56^{* *}$ \\
\hline Error & 28 & 4 & 6 & 1 & 1 & 1 & 12 & 6 & 5 & -7 & 27 \\
\hline \multicolumn{12}{|c|}{1991} \\
\hline Total & 39 & $23^{* *}$ & 0 & $13^{*}$ & 0 & 2 & $38^{* *}$ & $16^{*}$ & 8 & 0 & 100 \\
\hline Block & 4 & 2 & 0 & 2 & 0 & 0 & 4 & 0 & 0 & -6 & 3 \\
\hline Variety & 7 & $12^{* *}$ & 0 & $5^{*}$ & $0^{* *}$ & $1^{* *}$ & $18^{* *}$ & $6^{*}$ & $3^{*}$ & 24 & $69^{* * *}$ \\
\hline Error & 28 & 10 & 0 & 7 & 0 & 1 & 15 & 9 & 5 & -18 & 28 \\
\hline
\end{tabular}

Res $=$ residual.

'XX = compensation (product terms).

'The total sum of squares for marketable yield in grams per plant was 60,418 in 1990 and 357,653 in 1991 .

"A value of zero results from rounding 0.01 to 0.49 downward to zero.

"*** Significant at $P \leq 0.05$ or 0.01 , respectively.

$(r=0.9)$ but less strongly with leaf size $(r=$ $0.7)$, runner count $(r=0.5)$, and berry count $(r$ $=0.4$ ) per plant (Table 2). Marketable yield correlated negatively with truss and flower counts. Means for all yield components differed among varieties (Table 3).

In 199 1, variety differences accounted for $69 \%$ of the variation in marketable yield (Table 1). Variation in marketable yield for this year originated in fruit count (38\%), runner count $(23 \%)$, total yield $(16 \%)$, and crown count $(13 \%)$. Marketable yield correlated strongly with total yield $(r=0.9)$ and berry count $(r=$ 0.8 ) but less strongly with crown count $(r=$ $0.6)$ and truss count $(r=0.4)$ per plant (Table 2). Marketable yield correlated negatively with runner count per plant. Varieties had similar leaf size in 1991, but differed in all other yield components measured (Table 3 ).

In the planting year, as a group, 'Tristar', 'Irvine', 'Selva', and 'Fern' had the highest marketable yield. 'Ozark Beauty' was the lowest-yielding variety (Table 4). In 1991, 'Fort Laramie', 'Hecker', and 'Selva' had the highest marketable yield, while 'Irvine', 'Tribute', and 'Ozark Beauty' had the lowest. 'Selva' had the heaviest fruit and the fewest culls in 1990 and 1991 (Table 4).

Short-day-varieties. In a preliminary analysis, when data from 1990 and 1991 were combined, year effects accounted for $45 \%$ of the total variation in marketable yield and the variety $\times$ year interaction accounted for $14 \%$ (data not shown). Since the yields were much higher in 1991 than in 1990, the two years also were analyzed separately.

In 1990, variety differences accounted for $23 \%$ of the variation in marketable yield (Table 5). Total variation in marketable yield arose from total yield (39\%) and fruit count (23\%). Other components in 1990 did not contribute significantly to variation in marketable yield. Marketable yield correlated strongly with total yield (Table 2). Total yield and crown count did not differ significantly among the seven varieties but differed for all other yield components measured (Table 6). 'Pajaro' had the fewest runners and crowns, the most flowers and fruit, and the highest total and marketable yields. Conversely, 'Shuswap' had the most runners; the largest leaves; the fewest crowns, trusses, flowers, and fruit; and the lowest total and marketable yields (Table 6).

In 1991, varietal differences accounted for $61 \%$ of the variation in marketable yield (Table $5)$. Total variation in marketable yield for this year originated in runner count $(34 \%)$, total yield $(18 \%)$, and fruit count $(16 \%)$ per plant.

Marketable yield correlated strongly with total yield and moderately with runner and crown counts per plant (Table 2). Variety effects were nonsignificant for leaf size in 1991 but significant for all other measured yield components (Table 6). 'Shuswap' had the most runners and crowns and the highest marketable yield. 'Totem' had the largest leaves, the fewest trusses, and the lowest marketable yield.

Table 2. Correlations of yield components with marketable yield in a day-neutral and a short-day strawberry yield trial.

\begin{tabular}{|c|c|c|c|c|c|c|c|}
\hline \multirow[b]{2}{*}{ Source } & \multirow{2}{*}{$\begin{array}{c}\text { Runner } \\
\text { count }\end{array}$} & \multirow{2}{*}{$\begin{array}{c}\text { Leaf } \\
\text { size }\end{array}$} & \multicolumn{4}{|c|}{ Count } & \multirow{2}{*}{$\begin{array}{l}\text { Total } \\
\text { yield }\end{array}$} \\
\hline & & & Crowns & Trusses & Flowers & Fruit & \\
\hline \multicolumn{8}{|c|}{ Day-neutral } \\
\hline 1990 & $0.5^{* *}$ & $0.7^{* *}$ & -0.2 & $-0.5^{* *}$ & $-0.5^{* * *}$ & $0.4^{* *}$ & $0.9^{* *}$ \\
\hline 1991 & $-0.5^{* *}$ & -0.3 & $0.6^{* * *}$ & $0.4^{* *}$ & 0.3 & $0.8^{* *}$ & $0.9^{* *}$ \\
\hline \multicolumn{8}{|c|}{ Short-day } \\
\hline 1990 & -0.1 & -0.4 & -0.2 & 0.2 & 0.1 & 0.4 & $1.0^{* *}$ \\
\hline 1991 & $0.6^{* *}$ & 0.2 & $0.5^{*}$ & 0.2 & 0.3 & $0.5^{* *}$ & $0.9^{* *}$ \\
\hline
\end{tabular}

,*+* Significant at $P \leq 0.05$ or 0.01 , respectively.

Table 3. Mean values of yield components per plant for day-neutral strawberry varieties.

\begin{tabular}{|c|c|c|c|c|c|c|c|}
\hline \multirow[b]{2}{*}{ Variety } & \multirow{2}{*}{$\begin{array}{c}\text { Runner } \\
\text { count }\end{array}$} & \multirow{2}{*}{$\begin{array}{c}\text { Leaf } \\
\text { size } \\
\left(\mathrm{cm}^{2}\right)\end{array}$} & \multicolumn{4}{|c|}{ Count } & \multirow{2}{*}{$\begin{array}{c}\text { Total } \\
\text { yield } \\
\text { (g) }\end{array}$} \\
\hline & & & Crowns & Trusses & Flowers & Fruit & \\
\hline \multicolumn{8}{|c|}{1990} \\
\hline Fern & 5 & 55 & 3 & 6 & 45 & 22 & 217 \\
\hline Fort Laramie & 6 & 45 & 4 & 4 & 19 & 18 & 196 \\
\hline Hecker & 3 & 38 & 3 & 6 & 44 & 19 & 179 \\
\hline Irvine & 6 & 50 & 2 & 3 & 13 & 22 & 259 \\
\hline Ozark Beauty & 2 & 40 & 3 & 7 & 54 & 17 & 148 \\
\hline Selva & 4 & 58 & 2 & 1 & 15 & 10 & 200 \\
\hline Tribute & 1 & 44 & 2 & 3 & 24 & 19 & 184 \\
\hline Tristar & 5 & 57 & 3 & 5 & 29 & 26 & 243 \\
\hline F test & $* *$ & $* *$ & $* *$ & $* *$ & $* *$ & $* *$ & $* *$ \\
\hline LSD $(P \leq 0.05)$ & 1 & 7 & 1 & 1 & 9 & 6 & 49 \\
\hline \multicolumn{8}{|c|}{1991} \\
\hline Fern & 8 & 48 & 6 & 13 & 114 & 30 & 475 \\
\hline Fort Laramie & 3 & 45 & 10 & 19 & 108 & 46 & 648 \\
\hline Hecker & 4 & 45 & 6 & 17 & 137 & 47 & 630 \\
\hline Irvine & 10 & 48 & 4 & 9 & 56 & 16 & 243 \\
\hline Ozark Beauty & 10 & 46 & 6 & 19 & 135 & 33 & 474 \\
\hline Selva & 4 & 47 & 7 & 11 & 79 & 27 & 454 \\
\hline Tribute & 5 & 46 & 5 & 14 & 107 & 26 & 367 \\
\hline Tristar & 7 & 47 & 6 & 16 & 91 & 37 & 453 \\
\hline F test & $* *$ & NS & $* *$ & $* *$ & $* *$ & $* *$ & $* *$ \\
\hline LSD $(P \leq 0.05)$ & 4 & & 3 & 4 & $28^{\circ}$ & 6 & 102 \\
\hline
\end{tabular}

Ns,**Nonsignificant or significant at $P \leq 0.01$, respectively, as determined by analysis of variance. 
Table 4. Marketable yield, fruit weight, and percentage of culls of day-neutral strawberry varieties in 1990 and 1991.

\begin{tabular}{|c|c|c|c|c|c|c|}
\hline \multirow[b]{2}{*}{ Variety } & \multicolumn{2}{|c|}{$\begin{array}{l}\text { Marketable } \\
\text { yield } \\
\left(\mathbf{t} \cdot \mathrm{ha}^{-1}\right)\end{array}$} & \multicolumn{2}{|c|}{$\begin{array}{l}\text { Fruit } \\
\text { wt } \\
\text { (g) }\end{array}$} & \multicolumn{2}{|c|}{$\begin{array}{l}\text { Culls } \\
(\%)\end{array}$} \\
\hline & $\overline{1990}$ & $\overline{1991}$ & $\overline{1990}$ & $\overline{1991}$ & $\overline{1990}$ & 1991 \\
\hline Fern & 7.2 & 16.2 & 10 & 16 & 47 & 45 \\
\hline Fort Laramic & 6.0 & 26.3 & 12 & 14 & 49 & 34 \\
\hline Hecker & 5.2 & 23.5 & 9 & 14 & 54 & 40 \\
\hline Irvine & 8.0 & 12.1 & 12 & 16 & 50 & 26 \\
\hline Ozark Beauty & 2.4 & 15.6 & 9 & 14 & 74 & 47 \\
\hline Selva & 7.9 & 22.8 & 25 & 17 & 36 & 19 \\
\hline Tribute & 5.8 & 13.3 & 10 & 14 & 49 & 42 \\
\hline Tristar & 8.1 & 18.2 & 10 & 13 & 47 & 35 \\
\hline$F$ test & $* *$ & $* *$ & $*$ & $* *$ & ** & ** \\
\hline $\operatorname{LSD}(P \leq 0.05)$ & 1.9 & 4.8 & 9 & 1 & 9 & 5 \\
\hline
\end{tabular}

${ }^{* * * *}$ Significant at $P \leq 0.05$ or 0.01 , respectively, as determined by analysis of variance.

In the planting year, there were no significant varietal differences in marketable yield, fruit size, or percentage of culls (Table 7). In the second year, 'Shuswap' had the highest yield and 'Totem', 'Sequoia', and 'Puget Beauty' the lowest. 'Pajaro', 'Sequoia', and 'Shuswap' had the fewest culls in 1991 and 'Puget Beauty' the most. The varieties did not have significantly different fruit size in 1991.

Simple correlation analysis indicated that marketable yield and many of its components were correlated in day-neutral and short-day varieties. TDP indicated that, during the establishment year for day-neutral varieties, leaf size and runner count accounted for $41 \%$ of the variation in marketable yield. Thus, in this first year, varieties producing the most structural plant material, runners, and leaves produced the most fruit and had the highest total and marketable yields. Since runner count and leaf size were inserted into the TDP analysis of marketable yield before truss and flower counts, the latter did not seem to contribute significantly. Such a finding can depend on the sequence of fitting when, as in this case, truss and flower counts correlate with leaf size and runner count.

In the second year of the study with day-neutral plants, runner count again contributed a significant proportion $(23 \%)$ of variation in marketable yield. The correlation be- tween marketable yield and runner count in this year, however, was negative. Thus, varieties with fewer runners per plant produced higher marketable yields. By the second year, the plants were well established, and those plants producing fewer runners and more crowns also had more fruit and higher total and marketable yields.

Short-day varieties exhibited a different pattern in yield component production. In the planting year, the plants were establishing; thus, marketable yield was low and erratic. TDP analysis indicated that, in this year, the variation in marketable yield primarily was derived from fruit count and total yield. In the second year, the varieties produced commercially significant returns. Runner count, a measure of plant vigor, contributed $34 \%$ of the variation in marketable yield. In contrast to the study with day-neutral plants, short-day varieties with more runners produced higher marketable yields in the second year. Other measures of vegetative growth did not contribute significant levels of variation to marketable yield. Further variation in marketable yield in this year involved fruit count $(16 \%)$ and total yield $(18 \%)$.

Hesketh et al. (1990) attributed $65 \%$ of the variation in marketable yield of four short-day varieties to crown count per plant. However, much of this contribution was due to year and interaction effects present in the combinedyears analysis. Popenoe and Swartz (1985) suggested that relative contribution and importance of yield components varies with variety and growing system. Thus, to draw any parallels between different trials of different varieties would be difficult.

The cultural system used in the trial with short-day plants possibly resulted in the low contribution from measures of vegetative growth other than runner count. Short-day varieties traditionally have been grown in matted rows, where varietal selection would have favored those plant types capable of producing runners, crowns, and trusses to fill the rows. This choice is evident from the positive correlation between runner count and marketable yield, despite the fact that runners are removed when raised beds are used in production. This result directly contrasts the negative correlation between these characteristics for the day-neutral varieties that were selected for production on raised beds.

Among the day-neutral varieties evaluated, 'Selva' seemed well adapted for the Fraser River valley. It yielded within the top yielding group and had the largest fruit and the fewest culls during both years of the study. This finding is consistent with other varietal evaluations in British Columbia (Baumann and Eaton, 1991). In addition, consumer taste tests have indicated that 'Selva' is either preferred or indistinguishable from other day-neutral varieties (Shamaila et al., 1992).

All of the short-day varieties yielded more than 'Totem', presently the most popular local variety, in the second year of the study with short-day plants. Such results indicate that varieties adapted to one cultural methodmatted rows in the case of 'Totem'-will not necessarily do well under different growing conditions. 'Shuswap' had the largest marketable yield in 1991 and, along with 'Pajaro' and 'Sequoia', had the fewest culls. 'Shuswap', however, was a prolific producer of runners; thus, their removal in raised-bed production would be more expensive than with other varieties. 'Sumas' and 'Redcrest' yielded well without prolific runner production.

Table 5. Two-dimensional partitioning of the sum of squares for marketable yield for short-day strawberry varieties.

\begin{tabular}{|c|c|c|c|c|c|c|c|c|c|c|c|}
\hline \multirow[b]{4}{*}{ Source } & \multirow[b]{4}{*}{$\mathrm{df}$} & \multicolumn{10}{|c|}{ Variable } \\
\hline & & \multicolumn{9}{|c|}{ Independent } & \multirow{3}{*}{$\begin{array}{c}\text { Dependent } \\
\text { Marketable } \\
\text { yield }^{\mathbf{x}}\end{array}$} \\
\hline & & \multirow{2}{*}{$\begin{array}{c}\text { Runner } \\
\text { count }\end{array}$} & \multirow{2}{*}{$\begin{array}{l}\text { Leaf } \\
\text { size } \\
\end{array}$} & \multicolumn{4}{|c|}{ Count } & \multirow{2}{*}{$\begin{array}{l}\text { Total } \\
\text { yield }\end{array}$} & \multirow[b]{2}{*}{$\operatorname{Res}^{7}$} & \multirow[b]{2}{*}{$\mathrm{XX}^{\mathrm{y}}$} & \\
\hline & & & & Crowns & Trusses & Flowers & Fruit & & & & \\
\hline & & & & & 1990 & & & & & & \\
\hline Total & 23 & 2 & 11 & 14 & 4 & 6 & $23^{*}$ & $39^{* *}$ & $0^{w}$ & 0 & 100 \\
\hline Block & 3 & 0 & 0 & 0 & 0 & 0 & 5 & 6 & 0 & 7 & 19 \\
\hline Variety & 6 & $2^{4 *}$ & $10^{* *}$ & 2 & 2 & $5^{*}$ & 7 & 13 & 0 & -14 & 27 \\
\hline \multirow[t]{2}{*}{ Error } & 14 & 0 & 1 & 12 & 2 & 1 & 12 & 19 & 0 & 7 & 54 \\
\hline & & & & & 1991 & & & & & & \\
\hline Total & 23 & $34^{* *}$ & 4 & 3 & 15 & 3 & $16^{*}$ & $18^{*}$ & 8 & 0 & 100 \\
\hline Block & 3 & 3 & $1^{*}$ & 0 & 0 & $1^{*}$ & 1 & 3 & 1 & -2 & 8 \\
\hline Variety & 6 & $18^{* *}$ & $2^{* *}$ & $2^{* *}$ & 6 & $1^{*}$ & 5 & 8 & 3 & 16 & $61^{* *}$ \\
\hline Error & 14 & 12 & 1 & 1 & 8 & 1 & 11 & 7 & 4 & -13 & 32 \\
\hline
\end{tabular}

${ }^{2} \operatorname{Res}=$ residual.

${ }^{\mathrm{XX}}=$ compensation (product terms).

${ }^{x}$ The total sum of squares for marketable yield in grams per plant was 27,483 in 1990 and 51,352 in 1991 .

${ }^{\mathrm{w}} \mathrm{A}$ value of zero results from rounding 0.01 to 0.49 downward to zero.

*.** Significant at $P \leq 0.05$ or 0.01 , respectively. 
Table 6. Mean values of yield components per plant for short-day strawberry varieties.

\begin{tabular}{|c|c|c|c|c|c|c|c|}
\hline \multirow[b]{2}{*}{ Variety } & \multirow{2}{*}{$\begin{array}{c}\text { Runner } \\
\text { count }\end{array}$} & \multirow{2}{*}{$\begin{array}{c}\text { Leaf } \\
\text { size } \\
\left(\mathrm{cm}^{2}\right)\end{array}$} & \multicolumn{4}{|c|}{ Count } & \multirow{2}{*}{$\begin{array}{c}\text { Total } \\
\text { yield } \\
(\mathrm{g})\end{array}$} \\
\hline & & & Crowns & Trusses & Flowers & Fruit & \\
\hline \multicolumn{8}{|c|}{1990 . } \\
\hline Pajaro (1) & 2 & 44 & 1 & 2 & 9 & 3 & 89 \\
\hline Puget Beauty (2) & 9 & 40 & 2 & 1 & 2 & 2 & 70 \\
\hline Redcrest (3) & 5 & 45 & 2 & 1 & 4 & 2 & 18 \\
\hline Shuswap (4) & 8 & 63 & 2 & 0 & 0 & 0 & 0 \\
\hline Sumas (5) & 5 & 43 & 2 & 1 & 4 & 3 & 25 \\
\hline Totem (6) & 6 & 46 & 2 & 1 & 7 & 3 & 28 \\
\hline Sequoia (7) & 7 & 51 & 2 & 1 & 3 & 2 & 19 \\
\hline F test & $* *$ & $* *$ & NS & $* *$ & $* *$ & $* *$ & NS \\
\hline \multicolumn{8}{|c|}{ Contrasts } \\
\hline $1,7 / 2,3,4,5,6$ & $* *$ & NS & NS & $* *$ & $* *$ & * & NS \\
\hline $2,3 / 4,5,6$ & NS & $* *$ & NS & NS & NS & NS & NS \\
\hline $4 / 5,6$ & $* *$ & ** & NS & $* *$ & $* *$ & $* *$ & NS \\
\hline $1 / 7$ & $* *$ & $* *$ & NS & $*$ & $* *$ & NS & NS \\
\hline $5 / 6$ & NS & NS & NS & NS & $* *$ & NS & NS \\
\hline $2 / 3$ & $* *$ & $* *$ & NS & NS & NS & NS & NS \\
\hline \multicolumn{8}{|c|}{1991} \\
\hline Pajaro (1) & 2 & 55 & 3 & 4 & 16 & 9 & 150 \\
\hline Puget Beauty (2) & 3 & 48 & 3 & 3 & 13 & 11 & 132 \\
\hline Redcrest (3) & 4 & 55 & 3 & 3 & 13 & 11 & 179 \\
\hline Shuswap (4) & 10 & 58 & 5 & 2 & 11 & 12 & 205 \\
\hline Sumas (5) & 1 & 51 & 4 & 5 & 26 & 15 & 206 \\
\hline Totem (6) & 7 & 61 & 3 & 2 & 10 & 6 & 101 \\
\hline Sequoia $(7)$ & 4 & 67 & 3 & 2 & 6 & 5 & 86 \\
\hline F test & $*$ & NS & $* *$ & $* *$ & $* *$ & $* *$ & $* *$ \\
\hline \multicolumn{8}{|c|}{ Contrasts } \\
\hline $1,7 / 2,3,4,5,6$ & NS & NS & * & NS & NS & $* *$ & $*$ \\
\hline $2,3 / 4,5,6$ & NS & NS & $* *$ & NS & NS & NS & NS \\
\hline $4 / 5,6$ & $* *$ & NS & $*$ & $*$ & $*$ & NS & $*$ \\
\hline $1 / 7$ & NS & NS & NS & $*$ & NS & NS & NS \\
\hline $5 / 6$ & $*$ & $*$ & $*$ & $* *$ & $* *$ & $* *$ & $* *$ \\
\hline $2 / 3$ & NS & NS & NS & NS & NS & NS & $*$ \\
\hline
\end{tabular}

Ns,****Nonsignificant or significant at $P \leq 0.05$ and 0.01 , respectively.

Table 7. Marketable yield, fruit weight, and percentage of culls of short-day strawberry varieties in 1990 and 1991.

\begin{tabular}{|c|c|c|c|c|c|c|}
\hline \multirow[b]{2}{*}{ Variety } & \multicolumn{2}{|c|}{$\begin{array}{c}\text { Marketable } \\
\text { yield } \\
\left(\mathrm{t} \cdot \mathrm{ha}^{-1}\right) \\
\end{array}$} & \multicolumn{2}{|c|}{$\begin{array}{l}\text { Fruit } \\
\text { size } \\
(\mathrm{g})\end{array}$} & \multicolumn{2}{|c|}{$\begin{array}{c}\text { Culls } \\
(\%)\end{array}$} \\
\hline & 1990 & 1991 & 1990 & 1991 & 1990 & 1991 \\
\hline$\overline{\text { Pajaro (1) }}$ & 5.0 & 11.3 & 33 & 16 & 38 & 19 \\
\hline Puget Beauty (2) & 4.1 & 6.9 & 27 & 12 & 43 & 44 \\
\hline Redcrest (3) & 0.8 & 11.5 & 11 & 17 & 59 & 30 \\
\hline Shuswap (4) & 0.0 & 15.4 & 10 & 17 & 60 & 22 \\
\hline Sumas (5) & 1.4 & 10.8 & 10 & 14 & 38 & 43 \\
\hline Totem (6) & 0.9 & 6.0 & 10 & 20 & 66 & 37 \\
\hline Sequoia (7) & 1.1 & 6.4 & 11 & 16 & 41 & 19 \\
\hline$F$ test & NS & $* *$ & NS & NS & NS & $* *$ \\
\hline \multicolumn{7}{|c|}{ Contrasts } \\
\hline $1,7 / 2,3,4,5,6$ & NS & NS & NS & NS & NS & $* *$ \\
\hline $2,3 / 4,5,6$ & NS & NS & NS & NS & NS & NS \\
\hline $4 / 5,6$ & NS & ** & NS & NS & NS & $* *$ \\
\hline $1 / 7$ & NS & NS & NS & NS & NS & NS \\
\hline $5 / 6$ & NS & $*$ & NS & NS & * & NS \\
\hline $2 / 3$ & NS & NS & NS & NS & NS & $*$ \\
\hline
\end{tabular}

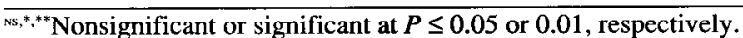

Day-neutral varieties outproduced shortday varieties in this study. Ninety-five percent confidence intervals on the means of the two experiments for marketable yield did not overlap. Such a result indicates a significant difference between the means of the short-day and day-neutral varieties studied. Day-neutral varieties produced higher yield during both years of the study. Day-neutral varieties in the raisedbed system can produce fresh fruit over a longer period than short-day varieties. The total yield per unit area evidently would be much higher from this system.

\section{Literature Cited}

Baumann, T.E. and G.W. Eaton. 1991. Season extension of day-neutral and ever-bearing strawberries in the hill row system. Adv. Strawberry Prod. 10:49-52.

Baumann, T.E., G.W. Eaton, and H.A. Daubeny. 1991. Season extension of short-day strawberries in the hill row system. Adv. Strawberry Prod. 10:43-48.

Baumann, T.E., G.W. Eaton, and D. Spaner. 1993. Changes in yield components due to plant spacing of short-day strawberries on raised beds. Adv. Strawberry Res. 12:30-33.

Baumann, T.E. and W.S. Peters. 1991. Grower manual for strawberry season extension. Ministry of Agr., Fisheries and Food, Victoria, B.C.

Eaton, G.W., P.A. Bowen, and P.A. Jolliffe. 1986. Two-dimensional partitioning of yield variation. HortScience 21:1052-1053.

Hesketh, J.L., G.W. Eaton, and T.E. Baumann. 1990. Strawberry plant spacing on raised beds. Fruit Var. J. 44:12-17.

Lawrence, F.J. 1989. Pacific Northwest strawberry cultivars. Fruit Var. J. 43: 19-21.

Popenoe, J. and H.J. Swartz. 1985. Yield component comparison of strawberry plants grown in various cultural systems. Adv. Strawberry Prod. 4:10-14.

Province of British Columbia. 1992. Annual statistics 1989. Ministry of Agr., Fisheries and Food, Victoria, B.C.

SAS Institute. 1985. SAS user's guide. version 5. SAS Institute, Cary, NC.

Shamaila, M., T.E. Baumann, G.W. Eaton, W.D. Powrie, and B.J. Skura. 1992. Quality attributes of strawberry cultivars grown in British Columbia. J. Food Sci. 57:696-699.

Steel, R.G.D. and J.H. Torrie. 1980. Principles and procedures of statistics: A biometrical approach. 2nd ed. McGraw-Hill, Montreal.

Swartz,H.J., J.Popenoe, and J.A.Fiola. 1985. Yield component analysis of the 1984 MarylandUSDA replicated trials. Adv. Strawberry Prod. 4:45-52. 